\title{
The Influence of The Use of The Square Quantum Learning Model on Poetry Writing Skills Students in Class VIII SMP Negeri 3 Kecamatan Payakumbuh
}

\author{
Hendrisman $^{1, a)}$ \\ ${ }^{1}$ Dosen PNSD STKIP Yayasan Abdi Pendidikan, Padang, Indonesia \\ E-mail: a) hendrisman63@gmail.com
}

\begin{abstract}
This study aims to describe (1) poetry writing skills of eighth grade students of SMP Negeri 3 Payakumbuh District using conventional methods. (2) poetry writing skills of eighth grade students of SMP Negeri 3 Payakumbuh District using a type of quantum learning model. (3) the effect of using the quantum teaching model of quantum teaching to the poetry writing skills of eighth grade students of SMP Negeri 3, Payakumbuh District. This research is using experimental method. Data analysis shows that the quantum teaching model of quantum tandur is influential in learning to write poetry in Indonesian subjects in the experimental class. This is due to an increase in student grades which at the time of the pre-test mean value $(\bar{X})$ is 67 . After applying the type of quantum learning model (quantum teaching) in the learning process at post-test with an average value $(\bar{X})$ is 80 . This is seen from the results of the comparison of tcount with table $(, 6798>2,021)$ because tcount is greater than table then Ha (alternative hypothesis) is accepted. So, the learning outcomes of experimental class students who are taught with quantum teaching models are better than the learning outcomes of control class students who are taught using conventional methods.
\end{abstract}

Keywords: learning model, quantum (quantum teaching), tandur type, poetry writing skills

\begin{abstract}
Abstrak
Penelitian ini bertujuan untuk mendeskripsikan (1) keterampilan menulis puisi siswa kelas VIII SMP Negeri 3 Kecamatan Payakumbuh menggunakan metode konvensional. (2) keterampilan menulis puisi siswa kelas VIII SMP Negeri 3 Kecamatan Payakumbuh menggunakan model pembelajaran kuantum (quantum teaching) tipe tandur. (3) pengaruh penggunaan model pembelajaran kuantum (quantum teaching) tipe tandur terhadap keterampilan menulis puisi siswa kelas VIII SMP Negeri 3 Kecamatan Payakumbuh. Penelitian ini menggunakan metode eksperimen. Analisis data menunjukkan bahwa model pembelajaran kuantum (quantumteaching) tipe tandur berpengaruh dalam pembelajaran menulis puisi pada mata pelajaran bahasa Indonesia di
\end{abstract}


kelas eksperimen. Hal ini dikarenakan adanya peningkatan nilai siswa yang mana pada waktu prates nilai rata-rata $(\bar{X})$ adalah 67 . Setelah diterapkan model pembelajaran kuantum(quantum teaching) tipe tandur dalam proses pembelajaran pada waktu pascates dengan nilai rata-rata $(\bar{X})$ adalah 80 . Hal ini di lihat dari hasil perbandingan thitung dengan tabel $(, 6798>2.021)$ karena thitung lebih besar dari tabel maka Ha (hipotesis alternatif) diterima. Jadi, hasil pembelajaran siswa kelas eksperimen yang diajar dengan model pembelajaran kuantum (quantum teaching) tipe tandur lebih baik dibanding hasil pembelajaran siswa kelas kontrol yang diajar menggunakan metode konvensional.

Kata kunci: model pembelajaran, kuantum (quantumteaching), tipe tandur, keterampilan menulis puisi

\section{PENDAHULUAN}

Bahasa dalam kehidupan sehari-hari digunakan untuk berkomunikasi baik bentuk lisan maupun tulisan dalam berinteraksi. Keterampilan berbahasa mencakup empat aspek, yaitu keterampilan menyimak, berbicara, membaca, dan menulis. Setiap keterampilan tersebut memiliki hubungan yang sangat erat sekali. Keterampilan menulis merupakan salah satu keterampilan yang harus dimiliki oleh setiap siswa, dengan memiliki kemampuan menulis siswa dapat mengekspresikan dan menuangkan ide, gagasan, dan pokok pikiran serta pengalaman. Puisi merupakan salah satu bagian dari karya sastra yang memiliki nilai keindahan. Dengan adanya pembelajaran tentang menulis puisi, siswa dapat mengetahui bentuk bahasa yang digunakan dalam menulis puisi (Satinem \& Juwati, 2019).

Menurut Kosasih (2008) puisi adalah bentuk karya sastra yang terkaji secara monolog, menggunakan kata-kata yang indah dan kaya akan makna. Keindahan puisi ditentukan oleh diksi, majas, rima, dan iramanya. Menurut Waluyo (2005) puisi adalah bentuk karya sastra yang mengungkapkan pikiran dan perasaan penyair secara imajinatif dan disusun dengan mengkonsentrasikan struktur batinnya. Menurut Wicaksono (2014: 21) pada hakikatnya puisi itu adalah salah satu karya sastra yang mempunyai nilai estetik (seni) yang tinggi dan berasal dari interpretasi pengalaman hidup manusia yang diubah dalam wujud yang paling berkesan atau sebagai hasil imajinasi dan gagasan penyair yang dituangkan dalam bentuk tipografi yang spesifik.

Menulis adalah proses mengubah pikiran/angan-angan/perasaan, menjadi bentuk lambing/tanda/tulisan yang bermakna (Sulkifli \& Marwati, 2016). Pembelajaran menulis merupakan salah satu gaya belajar yang unik. Menulis menekankan pada proses dan hasil. Hal ini menunjukkan bahwa menulis tidak serta merta dimiliki oleh seseorang akan tetapi memerlukan waktu untuk menghasilkan (Mahmud, 2017). Pembelajaran menulis merupakan salah satu pembelajaran yang memerlukan perhatian khusus baik oleh guru mata pelajaran atau pihak-pihak yang terkait dalam penyusunan kurikulum pembelajaran (Misra, 2017; Purwahida, 2018).

Menulis puisi berarti menuangkan pikiran, perasaan, gagasan kedalam bentuk tulisan yang menggunakan bahasa sebagai media penyampaiannya. Menulis puisi membutuhkan kreativitas yang tinggi dalam penciptaannya. Dengan banyaknya kosa kata yang dikuasai oleh penyair akan membantu menghasilkan puisi yang indah. Dilihat dari segi unsur-unsurnya, puisi memiliki unsur fisik dan unsur batin puisi. Unsur fisik 
puisi yaitu diksi, pengimajian, kata konkret, bahasa figuratif, rima, dan tata wajah. Unsur batin puisi yaitu tema, perasaan, nada dan suasana, amanat. Menulis puisi merupakan salah satu kompetensi dasar yang menjadi bagian dalam standar kompetensi kemampuan bersastra siswa kelas VIII Sekolah Menengah Pertama. Standar kompetensi tersebut mengharapkan siswa mampu mengungkapkan pikiran dan perasaan dalam puisi bebas. Oleh karena itu, keterampilan menulis puisi perlu ditanamkan kepada siswa di Sekolah Menengah Pertama (Prayitno, 2013; Purwahida, 2017). Keterampilan menulis puisi dianggap pembelajaran yang membosankan karena siswa beranggapan bahwa sulit untuk mencari kata-kata yang bersifat imaji atau khayalan. Model pembelajaran yang digunakan belum cukup efektif sehingga siswa kurang termotivasi dalam menulis. Pembelajaran yang masih sederhana dan kurang variatif membuat siswa kesulitan dalam menulis dan mengeluarkan ide-ide khususnya dalam menulis puisi. Siswa mengalami kesulitan dalam memahami konsep pembelajaran menulis karena siswa diajarkan dengan sesuatu yang kurang nyata atau melalui teori-teori saja tanpa praktek sehingga pembelajaran puisi sulit diterapkan model pembelajaran yang digunakan dalam menulis puisi adalah model pembelajaran kuantum.

Model pembelajaran merupakan seperangkat materi dan prosedur pembelajaran atas dasar landasan teoretis tertentu untuk tujuan pembelajaran tertentu (Sundari, 2015). Pembelajaran kuantum (quantum teaching) merupakan salah satu model pembelajaran yang berupaya membangkitkan motivasi, kreativitas, dan keterlibatan siswa secara langsung dalam proses belajar mengajar. Pembelajaran kuantum berfokus pada hubungan dinamis dalam lingkungan kelas serta interaksi yang menjadi landasan dan kerangka untuk berfikir. Interaksi dalam pembelajaran kuantum ini dapat mendukung efektivitas dalam pembelajaran, seperti halnya antusias dan semangat siswa dalam belajar. Interaksi tersebut juga mengubah kemampuan dan bakat alamiah siswa yang akan bermanfaat bagi mereka sendiri dan orang lain.

Menurut Wena (2011: 160) Model pembelajaran kuantum (quantum teaching) merupakan cara baru yang memudahkan proses belajar yang memadukan unsur seni dan pencapaian terarah untuk segala mata pelajaran. Menurut Suyatno (2004) pembelajaran kuantum merupakan pengubahan bermacam-macam interaksi yang ada di dalam dan di sekitar kegiatan belajar dengan menyingkirkan hambatan yang menghalangi proses belajar alamiah dengan secara sengaja menggunakan musik, mewarnai lingkungan sekeliling, menyusun bahan pengajaran yang sesuai, cara efektif pengajaran, dan keterlibatan aktif siswa dan guru. Menurut Basaria \& Leonard (2018) Tujuan dari pembelajaran kuantu, adalah sebagai berikut: 1) Untuk menciptakan lingkungan belajar yang efektif. 2) Untuk menciptakan proses belajar yang menyenangkan. 3) Untuk menyesuaikan kemampuan otak dengan apa yang dibutuhkan oleh otak. 4) Untuk membantu meningkatkan keberhasilan hidup dan karir. 5) Untuk membantu mempercepat dalam pembelajaran.

Tipe atau kerangka pembelajaran dari model pembelajaran kuantum ini yakni terdiri dari tandur. Tandur merupakan singkatan dari kata tumbuhkan, alami, namai, demontrasikan, ulangi, dan rayakan. Tandur ditunjukkan untuk meningkatkan minat siswa dalam belajar sehingga proses penyampaian materi dapat berjalan dengan baik (Cahyaningrum, dkk. 2019). Penggunaan model pembelajaran kuantum diharapkan dapat membantu siswa dalam menulis puisi karena model pembelajaran kuantum tipe tandur membantu siswa untuk merangkai kata-kata dalam puisi. Model pembelajaran kuantum diharapkan dapat membantu guru memperluas keterampilan siswa dan membangkitkan motivasi siswa. 


\section{METODE PENELITIAN}

Metode penelitian ini adalah eksperimen. Penelitian ini menggunakan paradigma The Randomized Posttest Only Control Group dalam pengumpulan data dan pengolahan data, serta menggunakan strategi penelitian eksperimen yang memerlukan data statistik. Penelitian ini menggunakan dua kelas kelompok sampel yaitu kelas eksperimen dan kelas kontrol. Kelas eksperimen menggunakan model pembelajaran kuantum tipe tandur, sedangkan kelas kontrol menggunakan metode konvensional. Pelaksanaan penelitian terhadap kedua kelas sampel diberi perlakuan yang berbeda. Kemudian dicari perbedaan rata-rata pengukuran dari kedua sampel diberi perlakuan dan perbedaan ini disebabkan oleh perlakuan. Perlakuan kedua kelompok diberi tes akhir (posttest). Maka desain penelitian yang digunakan adalah The Randomized Posttest Only Control Group (Yusuf, 2007:241). Menurut Sugiyono (2012: 243), teknik analisis data yang digunakan dalam penelitian kuantitatif yaitu diarahkan untuk menjawab rumusan masalah atau menguji hipotesis yang telah dirumuskan dalam proposal. Karena datanya kuantitatif, maka teknik analisis data menggunakan metode statistik yang sudah tersedia. Berdasarkan hal tersebut maka langkah-langkah yang akan dilakukan pada tahap analisis data adalah sebagai berikut (1) Membaca tulisan yang sudah dikumpulkan (2) Menentukan skor keterampilan siswa berdasarkan indikator-indikator yang diteliti (3) Mengubah skor menjadi nilai antara pretest dan posttest (4) Melakukan uji normalitas uji homogenitas dan uji hipotesis.

\section{HASIL DAN PEMBAHASAN}

Model pembelajaran kuantum (quantum teaching) tipe tandur merupakan model yang digunakan dalam keterampilan menulis puisi dengan tema perjuangan di kelas eksperimen. Kelas ekperimen menggunakan model pembelajaran kuantum (quantum teaching) tipe tandur, pertemuan pertama peneliti melakukan pretest, pertemuan kedua menjelaskan materi tentang puisi menggunakan model pembelajaran kuantum tipe tandur. Kelas kontrol diajarkan menggunakan metode konvesional, pertemuan pertama peneliti melakukan pretest, pertemuan kedua menjelaskan materi menggunakan metode konvensional, kemudian memberikan tes berupa tes unjuk kerja pada kedua kelas sampel dan tes unjuk kerja diperiksa berdasarkan skor yang telah ditentukan.

\section{Pengaruh Model Pembelajaran Kuantum Tipe Tandur pada Kelas Eksperimen}

Berdasarkan hasil dari prates dan pascates, maka didapat perhitungan statistik pada kelas eksperimen sebagai berikut:

Tabel 1.Data Statistik Kelas Eksperimen

\begin{tabular}{l|c|c}
\hline \multicolumn{1}{c|}{ Tes } & $\boldsymbol{\Sigma}$ & $\bar{X}$ \\
\hline Prates & 1593 & 64 \\
\hline Pascates & 2006 & 80 \\
\hline
\end{tabular}


Dari hasil tabel di atas dapat disimpulkan bahwa adanya pengaruh model pembelajaran kuantum tipe tandur dalam pembelajaran menulis puisi pada mata pelajaran Bahasa Indonesia di kelas eksperimen. Hal ini dibuktikan dengan adanya peningkatan nilai siswa, yang mana pada waktu prates total nilai $(\Sigma) 1593$ dan nilai ratarata/mean $(\bar{X})$ adalah 64. Setelah diterapkan model pembelajaran kuantum tipe tandurproses pembelajaran, terdapat peningkatan hasil pembelajaran siswa pada waktu pascates dengan total nilai $(\Sigma) 2006$ dan nilai rata-rata $(\bar{X}) 77$.

\section{Pengaruh Metode konvensional pada Kelas Kontrol}

Pada kelas kontrol, siswa diajarkan dengan menggunakan metode konvensional. Perhitungan statistik yang didapat setelah pascates pada kelas kontrol adalah sebagai berikut.

Tabel 2.Data Statistik Kelas Kontrol

\begin{tabular}{l|c|c}
\hline \multicolumn{1}{c|}{ Tes } & $\boldsymbol{\Sigma}$ & $\bar{X}$ \\
\hline Prates & 1430 & 57 \\
\hline Pascates & 1668 & 67 \\
\hline
\end{tabular}

Dari hasil tabel di atas dapat diambil kesimpulan bahwa adanya pengaruh metode konvensional terhadap pembelajaran menulis puisi kelas kontrol. Hal ini dibuktikan dengan adanya peningkatan nilai siswa, yang mana pada waktu prates total nilai $(\Sigma) 1430$ dan nilai rata-rata/mean $(\bar{X})$ adalah 57. Setelah menggunakan metodekonvensional, adanya peningkatan hasil pembelajaran siswa pada waktu pascates dengan total nilai $(\Sigma) 1668$ dan nilai rata-rata $(\bar{X}) 67$.

\section{Perbedaan Signifikan Antara Hasil Menulis Puisi dengan Menggunakan Model Pembelajaran Kuantum Tipe Tandur dan Metode Konvensional}

Untuk melihat perbedaan signifikan antara hasil pembelajaran menulis puisi dengan model pembelajaran kuantum tipe tandur dan metode konvensional, penulis melakukan perbandingan nilai pascates antara kedua kelas.

Tabel 3. Perbandingan Nilai Pascates

\begin{tabular}{l|l|c|l|l|c}
\hline \multicolumn{2}{c|}{ Kelas Eksperimen } & \multicolumn{3}{c}{ Kelas Kontrol } \\
\hline Jumlah Skor & $\mathrm{N}$ & $\bar{X}$ & Jumlah Skor & $\mathrm{N}$ & $\bar{X}$ \\
\hline 2006 & 25 & 80 & 1668 & 25 & 67 \\
\hline
\end{tabular}

Dari tabel di atas dapat dilihat rata-rata kelas eksperimen (77) lebih besar dibanding kelas kontrol (67). Hal ini menunjukkan bahwa adanya perbedaan yang signifikan antara hasil kemampuan menulis puisi siswa menggunakan model pembelajaran kuantum dibanding menggunakan metode konvensional. Dapat 
disimpulkan bahwa dalam penelitian ini penggunaan model pembelajaran kuantum lebih efektif dari pada penggunaan metode konvensional.

\section{Uji Normalitas}

Uji normalitas data dilakukan untuk menguji apakah data yang diteliti berdistribusi normal atau tidak.Untuk analisis datanya digunakan rumus Uji Liliefors. Pengujian ini dilakukan pada kedua kelas yaitu kelas eksperimen dan kelas kontrol, dan data yang digunakan adalah data dari hasil pascates. Data tersebut disimbolkan dengan $\mathrm{X}_{\mathrm{i}}$, setelah itu ditranformasikan dalam nilai $\mathrm{Zi}$ dari angka ke notasi pada distribusi normal dengan menggunakan dan Sd dari data. Selanjutnya dihitung probabilitas komulatif normal $\left(\mathrm{F}_{(\mathrm{zi})}\right)$ dan probabilitas komulatif empirisnya $\left(\mathrm{S}_{(\mathrm{zi})}\right)$. Kemudian diuji signifikansinya dengan menghitung selisih $\left\{\mathrm{F}_{(\mathrm{zi})}-\mathrm{S}_{(\mathrm{zi})}\right\}$, dan nilai terbesarnya (Liliefors hitung $=\mathrm{L}_{\mathrm{o}}$ ) dibandingkan dengan nilai Liliefors tabel $\left(\mathrm{L}_{\mathrm{t}}\right)$. Untuk mencari $\mathrm{L}_{\mathrm{t}}$ digunakan derajat kepercayaan $(\mathrm{dk} / \alpha)$ 0.05.Jika nilai $\mathrm{L}_{\mathrm{o}}<\mathrm{L}_{\mathrm{t}}$, maka data berdistribusi normal.Namun apabila $\mathrm{L}_{\mathrm{o}}>\mathrm{L}_{\mathrm{t}}$, maka data tidak berdistribusi normal. Hasil uji normalitas pada penelitian ini dapat dilihat pada tabel berikut:

Tabel 4.Hasil Perhitungan Uji Normalitas

\begin{tabular}{|c|c|c|c|c|c|c|c|}
\hline Kelas & $\mathbf{n}$ & $\overline{\boldsymbol{X}}$ & $\mathbf{S d}$ & $\mathbf{A}$ & $\mathbf{L}_{\mathbf{o}}$ & $\mathbf{L}_{\mathbf{t}}$ & Ket. \\
\hline Eksperimen & 25 & 80 & 11,3954 & 0.05 & $\begin{array}{c}0,1895 \\
9\end{array}$ & 0,1772 & Normal \\
\hline Kontrol & 25 & 67 & 13,4552 & 0.05 & 0,1768 & 0,1772 & Normal \\
\hline
\end{tabular}

Tabel di atas menunjukkan bahwa pada kedua kelas nilai Lo lebih kecil dibanding nilai Lt, ini berarti sebaran data pada hasil pembelajaran menulis puisi siswa yang diajar dengan model pembelajaran kuantum tipe tandur di kelas eksperimen dan metode konvensional di kelas kontrol berdistribusi normal.

\section{Uji Homogenitas}

Uji homogenitas dilakukan untuk melihat apakah data mempunyai varians yang homogen atau tidak.Pada penelitian ini, penulis menggunakan Uji Harley.Uji Harley digunakan dengan membandingkan variansi terbesar dengan variansi terkecil dari data. Kemudian hasil dari $F_{\text {hitung }}$ dibandingkan dengan hasil dari $F_{\text {tabel }}$, dengan $\mathrm{df}=\mathrm{n}$ 1 dan $\mathrm{k}=2$. Maka didapat hasil sebagai berikut:

Tabel 5. Hasil Perhitungan Uji Homogenitas

\begin{tabular}{|c|c|}
\hline$S_{1}^{2}$ & 140,743 \\
\hline$S_{1}^{2}$ & 279,892 \\
\hline $\mathrm{F}_{\text {hitung }}\left(\mathrm{F}_{\mathrm{n}}\right)$ & 0.50 \\
\hline $\mathrm{N}$ & 25 \\
\hline $\mathrm{K}$ & 2 \\
\hline $\mathrm{F}_{\text {tabel }}\left(\mathrm{F}_{\mathrm{t}}\right)$ & 3,4 \\
\hline
\end{tabular}

Dari tabel di atas dapat disimpulkan bahwa $F_{n}$ lebih kecil dari $F_{t}(0,50<3,40)$. ini berarti variansi dari penelitian ini bersifat homogen. 


\section{Uji t (t-test)}

Uji t merupakan langkah terakhir yang digunakan dalam penelitian ini. Uji t bertujuan untuk mencari nilai $t_{\text {hitung }}$ kemudian dibandingkan dengan nilai $t_{\text {tabel }}$, untuk menentukan hipotesis mana yang diterima. Sebelum melakukan uji $t$, peneliti mencari nilai standar deviasi gabungan $\left(\mathrm{S}_{\mathrm{gab}}\right)$ terlebih dahulu dengan rumus sebagai berikut:

$S_{g a b}=\frac{\left(n_{1}-1\right) S_{1}^{2}+\left(n_{2}-1\right) S_{2}^{2}}{n_{1}+n_{2}-2}$

Setelah didapat nilai ${ }_{b} \quad:$ :14,502maka nilai tersebut digunakan pada rumus uji t berikut ini:

$t=\frac{\overline{X_{1}}-\bar{X}_{2}}{S \sqrt{\frac{1}{n_{1}}+\frac{1}{n_{2}}}}$

Dari perhitungan tersebut didapat nilai $\mathrm{t}_{\text {hitung: }}: 98$. Kemudian nilai tersebut dibandingkan dengan nilai $t_{\text {tabel }}$ untuk menentukan hipotesis mana yang akan diterima, dan pembahasan tersebut dijelaskan pada pengujian hipotesis berikut.

\section{Pengujian Hipotesis}

Pengujian hipotesis dilakukan dengan membandingkan nilai prates dengan pascatesdari kelas eksperimen. Langkah awal adalah dengan menentukan dan Sd dari nilai skor masing-masing tes. Kemudian data tersebut digunakan untuk mencari standar deviasi gabungan $\left(\mathrm{S}_{\mathrm{gab}}\right)$. Langkah selanjutnya adalah dengan menggunakan data tersebut

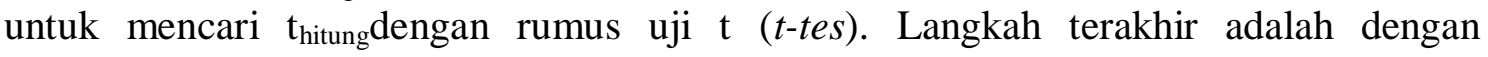
membandingkan nilai $t_{\text {hitung }}$ dengan $t_{\text {tabel. }}$. Hasilnya adalah sebagai berikut:

Tabel 6. Hasil Perhitungan Uji t Kelas Eksperimen

\begin{tabular}{|l|c|c|c|}
\hline \multicolumn{1}{|c|}{ Eksperimen } & N & $\overline{\boldsymbol{X}}$ & Sd \\
\hline Prates & 25 & 64 & 13,0751 \\
\hline Pascates & 25 & 80 & 11,3954 \\
\hline $\mathrm{S}_{\mathrm{d}}: 14,72952$ & \\
\hline $\mathrm{t}_{\text {hitung }}: 5,4312$ & \\
\hline $\mathrm{t}_{\text {tabel }}: 2.021$ (dengan df: $\mathrm{n}_{1}+\mathrm{n}_{2}-2=48$, dan $\left.: 0.025\right)$ \\
\hline
\end{tabular}

Dari tabel di atas dapat dilihat bahwa nilai $t_{\text {hitung }}$ lebih besar dari $t_{\text {tabel }}\left(t_{\text {hitung }}=\right.$ $5,4312 \mathrm{t}_{\text {tabel }}=2.021$ ). Ini berarti $\mathrm{H}_{\mathrm{a}}$ (hipotesis alternatif) diterima, yaituadanya pengaruh model pembelajaran kuantum tipe tandur terhadap keterampilan menulis puisi siswa kelas VIII.1 SMPNegeri3 Kecamatan Payakumbuh.

Pengujian hipotesis dilakukan dengan membandingkan nilai prates dengan pascates dari kelas eksperimen. Langkah awal adalah dengan menetukan dan Sd dari nilai skor masing-masing tes. Kemudian data tersebut digunakan untuk mencari standar deviasi gabungan $\left(\mathrm{S}_{\mathrm{gab}}\right)$. Selanjutnya dengan menggunakan data tersebut, untuk mencari

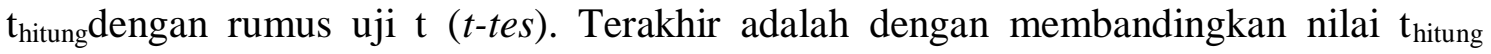
dengan $\mathrm{t}_{\text {tabel }}$. Hasilnya adalah sebagai berikut. 
Tabel 7. Hasil Perhitungan Uji t Kelas Kontrol

\begin{tabular}{l|l|l|c}
\hline \multicolumn{1}{c|}{ Kontrol } & $\mathbf{N}$ & & Sd \\
\hline Prates & 25 & 57 & 12,9807 \\
\hline Pascates & 25 & 67 & 13,4552 \\
\hline $\mathrm{S}_{\mathrm{d}}: 12,59958$ \\
\hline $\mathrm{t}_{\text {hitung }}: 3,9684$ \\
\hline $\mathrm{t}_{\text {tabel }}: 2.064\left(\right.$ dengan df: $\mathrm{n}_{1-1}-1=25$, dan $\left.: 0.05\right)$ \\
\hline
\end{tabular}

Dari tabel di atas dapat dilihat bahwa nilai $t_{\text {hitung }}$ lebih besar dari $t_{\text {tabel }}$ ( $t_{\text {hitung }}=3,9684>t_{\text {tabel }}=2.064$ ). Ini berarti $\mathrm{H}_{\mathrm{a}}$ (hipotesis alternatif) diterima, yaitu adanya pengaruh metode konvensional terhadap keterampilan menulis puisi siswa kelas VIII SMP Negeri 3 Kecamatan Payakumbuh.

Pengujian hipotesis dilakukan dengan membandingkan nilai dari kedua kelas yang didapat dari nilai pascates. Langkah awal dengan menentukan dan Sd dari tiap kelas, kemudian data tersebut digunakan untuk mencari standar deviasi gabungannya $\left(\mathrm{S}_{\mathrm{gab}}\right)$. Langkah selanjutnya dengan menggunakan data tersebut untuk mencari $\mathrm{t}_{\text {hitung }}$ dengan rumus uji $\mathrm{t}$ ( $t$-tes). Langkah terakhir adalah dengan membandingkan nilai $t_{\text {hitung }}$ dengan $t_{\text {tabel. }}$. Hasilnya adalah sebagai berikut.

Tabel 8.Hasil Perhitungan Uji t

\begin{tabular}{l|c|c|c}
\hline \multicolumn{1}{c|}{ Kelas } & $\mathbf{N}$ & $\overline{\boldsymbol{X}}$ & Sd \\
\hline Eksperimen & 25 & 80 & 11,8635 \\
\hline Kontrol & 25 & 67 & 6,73 \\
\hline $\mathrm{S}_{\text {gab }}: 14,502$ & \\
\hline $\mathrm{t}_{\text {hitung: }} \quad 6798$ \\
\hline $\mathrm{t}_{\text {tabel }}: 2.021$ (dengan df: $\mathrm{n}_{1}+\mathrm{n}_{2}-2=48$ dan $\left.: 0.05\right)$ \\
\hline
\end{tabular}

Dari tabel di atas dapat dilihat bahwa nilai $t_{\text {hitung }}$ lebih besar dari $t_{\text {tabel }}\left(t_{\text {hitung }}=\right.$ 798 $>t_{\text {tabel }}=2.021$ ). Ini berarti $\mathrm{H}_{\mathrm{a}}$ (hipotesis alternatif) diterima, yaitu adanya perbedaan yang signifikan antara kemampuan menulis puisiyang diajar dengan model pembelajaran kuantum tipe tandur dibanding dengan siswa yang diajar dengan metode konvensional.

\section{KESIMPULAN}

Hasil dari suatu penelitian dapat disimpulkan bahwa model pembelajaran kuantum (quantum teaching) tipe tandur berpengaruh dalam pembelajaran menulis puisi di kelas eksperimen. Hal ini dibuktikan adanya peningkatan nilai siswa, yang mana pada waktu tes awal nilai rata-rata/mean $(\bar{X})$ adalah 64 . Setelah diterapkan model pembelajaran kuantum tipe tandur dalam proses belajar di kelas eksperimen diperoleh peningkatan hasil pembelajaran siswa pada waktu tes akhir dengan nilai rata-rata $(\bar{X}) 80$, dengan uji t ( $t$-test) membuktikan $t_{\text {hitung }}$ dengan $t_{\text {tabel }}(5,4312>2,021)$, 
karena $t_{\text {hitung }}$ lebih besar dari $t_{\text {tabel }}$ maka $\mathrm{H}_{\mathrm{a}}$ (hipotesis alternatif) diterima. Jadi, hasil pembelajaran siswa di kelas eksperimen yang diberi perlakuan dengan model pembelajaran kuantum tipe tandur berpengaruh dengan sebelum diberi perlakuan. Berdasarkan hasil penelitian menggunakan metode konvensional berpengaruh dalam pembelajaran menulis puisi di kelas kontrol. Hal ini dibuktikan dengan adanya kenaikan nilai siswa. Pada tes awal diperoleh rata-rata/mean $(\bar{X})$ adalah 57. Setelah diterapkan pembelajaran konvensional dalam proses belajar di kelas kontrol, didapat peningkatan hasil pembelajaran siswa pada waktu tes akhir dengan nilai rata-rata $(\bar{X}) 67$, dengan uji $\mathrm{t}(t$-test $)$ membuktikan $\mathrm{t}_{\text {hitung }}$ dengan $\mathrm{t}_{\text {tabel }}(3,9684>2.064)$, karena $t_{\text {hitung }}$ lebih besar dari $t_{\text {tabel }}$ maka $\mathrm{H}_{\mathrm{a}}$ (hipotesis alternatif) diterima. Jadi, hasil pembelajaran siswa di kelas kontrol yang diberi perlakuan dengan pembelajaran konvensional berpengaruh dengan sebelum diberi perlakuan.

Berdasarkan hasil penelitian, model pembelajaran kuantum (quantum teaching) tipe tandur berpengaruh dalam keterampilan menulis puisi di kelas eksperimen. Hasil uji t diketahui bahwa adanya perbedaan yang signifikan antara hasil keterampilan menulis puisi antara model pembelajaran kuantum tipe tandur dengan metode konvensional. Hal ini dapat dilihat pada hasil perbandingan $t_{\text {hitung }}$ dengan $t_{\text {tabel }}(6798>2.021)$, karena $t_{\text {hitung }}$ lebih besar dari $t_{\text {tabel }}$ maka $\mathrm{H}_{\mathrm{a}}$ (hipotesis alternatif) diterima. Jadi, hasil pembelajaran siswa di kelas eksperimen yang diberi perlakuan dengan model pembelajaran kuantum tipe tandur lebih baik dibanding dengan hasil pembelajaran siswa di kelas kontrol yang diberi perlakuan dengan pembelajaran konvensional.

Berdasarkan kesimpulan dari hasil penelitian di atas, maka penulis memaparkan beberapa saran, yaitu siswa lebih kreatif dalam belajar dan terus berlatih dalam kegiatan menulis. Guru lebihkreatif dan aktif menggunakan model pembelajaran untuk meningkatkan minat belajar siswa, sehingga siswa tidak merasa bosan saat proses belajar mengajar. Sekolah dapat menyediakan segala kebutuhan, sarana, dan prasarana yang dapat menunjang kegiatan belajar siswa. Peneliti selanjutnya agar dapat melanjutkan penelitian ini dengan menggunakan model pembelajaran yang berbeda, menarik, dan kreatif untuk mendapatkan hasil yang lebih baik lagi.

\section{UCAPAN TERIMA KASIH}

Peneliti menyampaikan ucapan terima kasih kepada kepada STKIP Yayasan Abdi Pendidikan yang telah memberikan izin penelitian kepada peneliti, SMP Negeri 3 Kecamatan Payakumbuh atas pemberian izin untuk dapat melakukan penelitian disekolah, dan Tim redaksi Jurnal Aksis atas saran dan Masukkan untuk perbaikan penulisan artikel ini.

\section{REFERENSI}

Arikunto, Suharmi. (2006). Prosedur Penelitian Suatu Pendekatan Praktik. Jakarta: Rineka Cipta.

Basaria, N. \& Leonard. (2018). Model Pembelajaran Quantum Learning dengan Strategi Pembelajaran Tugas dan Paksa. Universitas Indraprasta PGRI Jakarta. Seminar Nasional dan Diskusi Panel Multidisiplin Hasil Penelitian \& Pengabdian kepada Masyarakat. 
Cahyaningrum, A.D. dkk. (2019). Pengaruh Model Pembelajaran Quantum Teaching Tipe Tandur Terhadap Hasil Belajar. Indonesian Journal of Science and Mathematics Education. doi: 10.24042/IJSME.v2i3.4363.

Kosasih, E. (2008). Apresiasi Sastra Indonesia. Jakarta: Nobel Edumedia.

Mahmud, H. (2017). Upaya Meningkatkan Keterampilan Menulis dengan Teknik RCG (Reka Cerita Gambar) Pada Siswa Kelas VI SDN Rengkak Kecamatan Kopang, Kabupaten Lombok Tengah Tahun Pelajaran 2017/2018. JISIP Volume 1 (2) ISSN 2598-9944.

Misra. (2017). Peningkatan Kemampuan Menulis Pengumuman Melalui Metode Latihan Siswa Kelas IV SD Inpres 2 Gio Kecamatan Moutong. Jurnal Kreatif Tadulako Online Volume 1 (2) ISSN 2354-614X

Prayitno, Hendi. W. (2013). Peningkatan Keterampilan Menulis Puisis Menggunakan Teknik Inkuiri dan Latihan Terbimbing. Unnes: Jurnal Pendidikan Bahasa dan Sastra Indonesia Volume 2 (1).

Purwahida, R. (2017). Interaksi sosial pada kumpulan cerpen Potongan Cerita di Kartu Pos karangan Agus Noor dan implikasinya terhadap pembelajaran sastra di SMA. Aksis: Jurnal Pendidikan Bahasa dan Sastra Indonesia 1(1). 118-134. doi: doi.org/10.21009/AKSIS.010107

Purwahida, R. (2018). Problematika Pengembangan Modul Pembelajaran Baca Tulis Anak Usia Sekolah Dasar. Aksis: Jurnal Pendidikan Bahasa dan Sastra Indonesia 2(1). 118-134. doi: doi.org/10.21009/AKSIS.020108

Satinem \& Juwati. (2019). The Diction And Language Style In Sutardji Calzoum Bachri's Contemporary Poetry (A Study On Stilistics). Aksis: Jurnal Pendidikan Bahasa dan Sastra Indonesia 3(1). 154-167. doi: doi.org/10.21009/AKSIS.030115

Sugiyono. (2012). Metode Penelitian Kuantitatif, Kualitatifdan R\&D. Bandung: Alfabeta.

Sundari, H. (2015). Model-model Pembelajaran dan Pemerolehan Bahasa Kedua/Asing. Universitas Indraprasta PGRI Jakarta: Jurnal Pujangga Volume $1(2)$.

Sulkifli \& Marwati. (2016). Kemampuan Menulis Puisis Siswa Kelas VII SMP Negeri Satu Atap 3 Langgikima Kabupaten Konawe Utara. FKIP UHO: Jurnal Bastra Volume 1 (1).

Suyatno. (2004). Teknik Pembelajaran Bahasa dan Sastra. Surabaya: SIC

Waluyo. Herman. J. (2005). Apresiasi Puisi. Jakarta: Gramedia 
Wicaksono. (2014). Menulis Kreatif Sastra dan Beberapa Model Pembelajarannya. Yogyakarta: Garuda Waca.

Wena, Made. (2011). Strategi Pembelajaran Inovatif Kontemporer. Jakarta: Bumi Aksara.

Yusuf, A. Muri. (2007). Metodologi Penelitian.Padang: UNP Press. 